\title{
Industrial Output and Economic Growth in Emerging Economies: Evidence from Nigeria
}

\author{
Stephen Ebhodaghe Ughulu ${ }^{1}$ \\ ${ }^{1}$ Department of Banking and Finance, Igbinedion University, Okada, Edo State of Nigeria. \\ Correspondence: Dr. Stephen Ebhodaghe Ughulu, Department of Banking and Finance, Igbinedion University, Okada, \\ Edo State of Nigeria.
}

Received: November 20, 2020

Accepted: February 15, 2021

Available online: February 23, 2021

doi:10.11114/afa.v7i1.5175

URL: https://doi.org/10.11114/afa.v7i1.5175

\begin{abstract}
The importance of the industrial sector output in enhancing sustainable economic growth has long been documented given that the sector is generally perceived as the engine of growth in an economy. This notwithstanding, Nigeria seems not to have put in place appropriate policies and programs that would engender the desired industrial output growth. The main aim of the paper, therefore, is to examine empirically the relationships between industrial sector output and the sustainable economic growth of Nigeria for the period 1981 to 2018. In doing this, descriptive statistics, unit root and co-integration tests as well as long run and short run analyses were conducted using the error correction model (ECM) of the econometrics. The empirical results from these estimation procedures were quite revealing. For instance, there existed a positive relationship between industrial sector output and economic growth though this was weak considering the magnitude of effects. Capital expenditure and lending rate exerted negative relationships on industrial output and these tended to have accounted for the current low level of industrial activities in the country. The stability test carried out in the paper showed a significant structural stability, which affirmed that these results have called for appropriate policy options that would bring about the desired industrial sector output growth patterns. Hence, strengthening the industrial sector activities in Nigeria as well as streamlining capital expenditure and lending rate to enhance the sector's output has become imperative. This is typically true as it is the only path that would lead to the enhancement of the industrial sector output and, invariably, the sustainable economic development that Nigeria desperately desires.
\end{abstract}

Keywords: industrial output, economic growth, capital expenditure, trade openness, lending rate

JEL: O14, L11, F43, N17, C32

\section{Introduction}

When the economy of a developing nation participates more with global market activities as it grows, it can then be classified as an emerging market economy (Gordon Scott, https:www.investopedia.com). Countries in this category have some characteristics that are similar to those obtainable in developed markets. In a more specific manner, Tutor $2 u$ (2020) defines an emerging country as one in which the country is becoming a developed nation often driven by relatively high economic growth and a rapid expansion of trade and investment flows. Since the mid-1990s, there has been a gradual growth in the Nigerian economy. For instance, Nigeria's real gross domestic product (RGDP) grew by about 6.27 per cent, 7.57 per cent, and 7.38 per cent for the years 2009, 2010 and 2011, respectively (National Bureau of Statistics, 2013).

Perhaps, this seemingly enviable economic performance as well as the relative huge size of the country coupled with its large population helped Nigeria to attain the status of an emerging market economy alongside some countries such as Argentina, Egypt, Hungary, India, etc., (Institute of International Finance, 2017; World Economic Situation and Prospect, 2018). However, the World Bank (2018) reported that after the recession in 2015 and 2016, Nigeria's GDP growth rate was about 3.23 per cent, while the annual GDP growth rate stood at 0.55 per cent during the same period. The World Bank further reported that the structure of the Nigerian economy is dominated by the primary sector with the agricultural and oil and gas sectors accounting for about 95 per cent and 85 per cent of export earnings and national income, respectively. The implication of this is that the country's growth in GDP depended largely on the primary sector rather than the industrial sector. This type of scenario is somewhat worrisome considering that the industrial 
sector is generally acknowledged as the productive base of an economy (Anyanwu, Oyefusi, Oaikhenan \& Dimowo, 1997). Nigeria's Fourth Development Plan lent credence to this assertion when it stated that the industrial sector could help in the sustenance of a minimum growth rate of about 15 per cent annually, as the sector is expected to be responsible for the largest employment generation within the economy, and also enhance the value of natural resources, among others. This is typically true given that both theory and empirical evidence have shown that the industrial sector of the economy has positive implications for economic growth.

Despite various policy efforts aimed at revamping the Nigerian industrial sector over the years, as exacerbated by the promulgation of the Indigenization Decree of 1972, as well as the introduction of the Structural Adjustment Program in 1985/86, the establishment of the Bank of Industry (BOI), amongst others, the industrial sector still accounts for a meager proportion of economic activity - hovering around 4 per cent and 6 per cent (NBS, 2005, 2011 and 2018). This is far below what is obtainable on the average in countries like China (about 32.1 per cent), Indonesia (about 27 per cent), South Africa (about 17.7 per cent) and Egypt (about 17.5 per cent) (World Bank, 2016). Some studies (see, for example, Mandara \& Ali (2018), Gylych \& Enwerem (2016), Jelilov, Enwerem \& Isik (2016), Benneth, Anyanwu \& Kalu (2015) which have been conducted to verify the impact of industrial sector output on economic growth appeared with mixed outcomes.

The gyration in the nominal national statistics of Nigeria as enunciated above serves as the motivation for the paper. Thus, the thrust of the paper is to examine empirically the relationships between the RGDP (denoted as the dependent variable) and industrial sector output, capital expenditure, lending rate, and trade openness (which serve as the independent variables) for the period 1981 to 2018. The rest of the paper is structured as follows: section 2 reviews the literature, section 3 contains methodology, section 4 analyzes data and interprets results, while section 5 gives the findings, conclusion and recommendations of the paper.

\section{Literature Review}

This section focuses on literature review and is organized into conceptual issues and empirical reviews, thus:

\subsection{Conceptual Issues}

\subsubsection{Economic Growth}

Economic growth refers to the ability of the economy to increase the production of goods and services with the stock of capital and other factors of production within the economy (Nnanna, O.J., Englama, A and Odoko, F.O. (2004)). Thus, it entails increases in per capita income that leads to the attainment of a high standard of living equivalent to that of industrial countries (Todaro \& Smith, 2011; Ughulu \& Ajayi, 2020). In this sense, economic growth can be seen as an aspect that fuels the process of economic development (Sen, 1983).

\subsubsection{Industrial Sector Output}

Industrial sector output can be defined as the total production of the output by the industrial establishments within the economy and covers such sectors as mining, manufacturing, electricity, gas and steam and air-conditioning (OECD, 2020). This indicator is usually measured as an index based on a reference period that expresses change in the volume of production output. Put differently, industrial production measures the output of the industrial sector, which typically comprises mining, manufacturing, utilities and, in some cases, construction. It is generally taken as an index in volume terms. Annual variation in industrial production as a percentage thus reflects the change in the volume of industrial output as compared to the previous year. This is to say that annual variation in industrial production provides an insight into the state of the economic cycle as the production of consumer durables and capital goods is likely to decrease during an economic downturn. Despite the fact that the industrial sector only accounts for a portion of an economy's total output, it is a leading indicator of gross domestic product (GDP) growth and economic performance due to its sensitivity to consumer demand and interest rates.

\subsubsection{Capital Expenditure}

Capital expenditure involves the money spent on the acquisition of assets such as land, buildings, machinery, equipment as well as investment in shares (Wikipedia, 2020). In other words, capital expenditure entails the money an organization or a corporate entity spends to buy, maintain or improve its fixed assets such as buildings, vehicles, equipment, or land. In a similar vein, Accounting Coach (2020) defines capital expenditure as an amount spent to acquire or significantly improve the capacity or capabilities of a long-term asset such as equipment or buildings.

\subsubsection{Lending Rate}

Lending rate is the other-depository corporation rate that usually meets the short- and medium-term financing needs of the private sector. It is normally differentiated according to the creditworthiness of borrowers and objectives of financing (Datahelp.imf.org). According to trading economics, lending rate in Nigeria is estimated to stand at 14.42 per 
cent in 12 months time. In the long-term, the Nigerian lending rate is projected to trend around 14.42 per cent in 2021, according to the country's econometric models (https://tradingeconomics.com).

\subsubsection{Trade Openness}

Trade openness is one measure of the extent to which a country is engaged in the global trading system. It is usually measured by the ratio between the sum of exports and imports and gross domestic product (GDP). In this sense, trade openness can potentially enhance economic growth by providing access to goods and services, achieving efficiency in the allocation of resources and improving total factor productivity through technology diffusion and knowledge dissemination (Barro \& Sala-i-Martins, 1997). An empirical measure of trade openness is defined as the ratio of total trade to GDP, and represents a convenient variable routinely used for cross-country studies on a variety of issues. However, the effects that the crude measure captures remain ambiguous, making it difficult to interpret the empirical results (Huchet-Bourdon, Mouel \& Vijil, 2018).

\subsection{Empirical Review}

A plethora of some studies exists in the extant literature. For example, Mandara \& Ali (2018) examined the impact of industrialization on the Nigerian economy for the period 1981 to 2015. These authors utilized the ARDL model of the econometrics to evaluate the data of their study. Some of their findings showed that industrial output exerted a positive and significant impact on economic growth. Furthermore, the ECM result of their study revealed that the disequilibrium that occurred due to shocks was appropriately corrected in the sixteenth quarter at about 6 per cent per quarter. Hence, they recommended that the enactment and implementation of certain statutes and policies aimed at strengthening industrial development in Nigeria becomes imperative. Similarly, Abdu \& Anam (2018) examined the effect industrial sector output on the Nigerian economy spanning from 1981 to 2016. The STATA estimation technique was employed to analyze the study's data. The results that emanated from their estimation exercise revealed that industrial output in Nigeria exerted a positive and significant impact on economic growth during period covered by their study. The authors therefore recommended, amongst others, that policy makers should as a matter of importance and urgency introduce and implement policies that are aimed at developing the industrial sector and, invariably, the overall Nigerian economy.

Quaicoe, Aboagye and Bokpin (2017) investigated the impact of the export processing zones on economic growth in Ghana using quarterly time series data for the period 1998 to 2015. The vector error correction model (VECM) technique was employed to evaluate the data of their study. Their findings showed that the export processing zones exhibited a negative but significant impact on economic growth in Ghana. In the same vein, Senibi, Akiyepeku, Odutola, Ndaman, Eseoghene, Ogunlusi \& Eldad (2017) examined the impact of the industrial sector output on the Nigerian for the period 1981 to 2013 . The study utilized the co-integration and granger causality techniques to estimate the results of their study. Their findings showed that a negative but significant long run impact existed between industrial sector output and Nigeria's economic growth. The Granger causality tests of their work revealed that a one-way causality running from industrial output to economic growth thus existed. Hence, they strongly recommended that frantic efforts should be made by appropriate authorities to promote an enabling environment that would induce higher industrial output that will lead to a rapid and sustainable economic growth in Nigeria.

Gylych and Enwerem (2016) examined the impact of industrialization on the economic growth of ten Economic Community of West African States (ECOWAS) countries from 2000 to 2013. The ordinary least squares (OLS) estimation technique was adopted to process the data of their study. Their empirical results revealed that industrialization exerted a negative impact on the economic growth of these countries in the long run. They therefore strongly recommended that the appropriate authorities of these countries should take immediate steps to introduce necessary policies that would help to protect their infant industries thereby enhancing the industrial sector outputs that would certainly enthrone economic prosperity in their respective countries. Jelilov, Enwerem and Isik (2016) investigated the impact of industrialization on growth in Nigeria for the period 2000-2013. The OLS and F-test analytical techniques were used to estimate the results of their study. The finding of their study showed that on the long run, industrialization exerted a negative impact on economic growth in Nigeria. Accordingly, they recommended that appropriate industrialization and investment policies aimed at increasing productivity and growth should be urgently put in place.

Bennett, Anyanwu and Kalu (2015) conducted a study on the effect of industrial sector output on economic growth in Nigeria for the period 1973 to 2013. The PC Give 8.00 analytical technique was employed to analyze the data of their study. The empirical results thus obtained revealed that industrial sector output exhibited a positive but insignificant effect on Nigeria's economic growth. They therefore recommended the initiation and implementation of those policies that are thought germane to increased industrial sector output and, hence, economic growth. In another effort, Adenomon and Oyejola (2013) examined the impact of the agricultural and industrial sectors' output on Nigeria's economic growth for the period 1960 to 2011. The empirical results from of their study using the VAR and SVAR approaches showed that the agricultural and industrial sectors' outputs accounted for about 58 per cent and 32 per cent, 
respectively, of Nigeria's GDP within the afore-mentioned period. The authors therefore recommended that relevant policy measures should be faithfully implemented for the industrial sector to be well positioned to contribute positively to the growth of the Nigerian economy. Tamuno and Edoumiekumo (2012) examined the nexus of industrialization, trade and economic growth in Nigeria. The co-integration data analysis technique was employed to generate the results of their study, which showed that the industrial sector is yet to contribute meaningfully to economic growth in Nigeria. They therefore recommended that appropriate policies aimed at exporting refined agricultural products rather than primary agricultural produce should be encouraged without further delay to enhance economic growth which Nigeria desperately desires.

Udah (2010) examined the interrelationships amongst industrial development, electricity and economic growth in Nigeria for the period 1970 to 2008 using the ECM technique. The result of his study revealed that industrial sector output and electricity supply were positively related to economic growth in Nigeria. Similarly, Akpan, Riman, Duke II \& Mboto (2012) examined the impact of industrial output and non-oil export on economic growth in Nigeria employing the VECM technique. The result from their analysis showed that industrial output and non-oil exports exhibited a positive and significant impact on economic growth in Nigeria through a one-way causality running from industrial output to non-oil exports. They therefore recommended strongly that policies that could attract and strengthen industrial development in Nigeria be put in place as a matter of deliberate efforts and utmost urgency.

\section{Theoretical Framework and Model Specification}

\subsection{Theoretical Framework}

The theoretical framework of the paper is derived from the endogenous growth theory, which posits that the industrial sector must bring about positive relationships between the industrial sector output and other macroeconomic variables relative to growth. Many researchers (see, for example, Barro, 1991; Okodua, 2012; and Izebigie, Isikhuemen \& Ogbeifun (2020), have used this theoretical framework to develop the models of their respective studies.

\subsection{Model Specification}

Based on the theoretical postulations in 3.1 above, the functional form of the model specified for the study is presented, thus:

$$
R G P=f(I N Q, C E X, L D R, T O P) \quad \ldots \quad \ldots
$$

Where,

$\mathrm{RGP}=$ Growth rate of real GDP per capita, INQ = Industrial Output, CEX $=$ Capital Expenditure, $\mathrm{LDR}=$ Lending Rate, TOP $=$ Trade Openness.

Rewriting equation (1) in the long run relationship in the log form yields equation (2) as follows:

$$
\ln R G P=\beta_{0}+\beta_{1} \ln I N Q_{t}+\beta_{2} \ln C E X_{t}+\beta_{3} L D R_{t}+\beta_{4} \ln T O P_{t}+\mu_{t}
$$

Where,

$\beta_{1}, \beta_{2}, \beta_{3}, \beta_{4}, a_{1}, a_{2}, a_{3}, a_{4}=$ are parameters of coefficients, $U_{t}=$ stochastic term, $l n=$ lagged estimates

However, the eschewing error correction model (ECM) that will generate the parsimonious representation gives equation (3), viz:

$$
\ln R G P=a_{0}+a_{1} \ln I N Q_{t}+a_{2} \ln C E X_{t}+a_{3} L D R_{t}+a_{4} \ln T O P_{t}+\phi E C M_{t-1}+\mu_{t}
$$

.A priori signs of the variables (with the exception of lagged ECM) are indeterminate. This means that they could either be positive or negative.

The ECM estimation technique using the OLS procedure will be conducted via the unit root and co-integration analysis tests. The choice for this methodology stems from the fact that it is amenable to analyzing both long and short run dynamics of the outcomes of the estimation of the paper. The procedure also ensures that estimates are not spurious (Hendry, 1986). For the ECM to effectively perform this role, the lagged residual coefficient (speed of adjustment, that is, how quickly equilibrium is restored in the temporary displacements that occurred from the unit root and cointegration tests) must be negatively signed and statistically significant. The data for the estimation exercise covered the period 1981-2018 and were sourced from World Bank, World Development Indicators (2019) and the Central Bank of Nigeria (2019).

\section{Data Analysis and Interpretation of Results}

This section carries out data analysis and interpretation of results as follows: 


\subsection{Descriptive Statistics}

The descriptive statistics obtained from the estimation exercise of the paper are contained in Table 4.1 below:

Table 1. Descriptive Statistics

\begin{tabular}{|l|l|l|l|l|l|l|}
\hline & RGP & INQ & CEX & LDR & TOP \\
\cline { 2 - 7 } & Mean & 33725.22 & 5555.150 & 426.2259 & 17.57657 & 4879.924 \\
\hline Median & 23068.85 & 1639.590 & 289.3337 & 17.54000 & 979.9450 \\
\hline Maximum & 69810.02 & 26129.91 & 1682.099 & 29.80000 & 21918.44 \\
\hline Minimum & 13779.26 & 37.02000 & 4.100100 & 7.750000 & 12.49000 \\
\hline Std. Dev. & 19578.10 & 7291.427 & 441.8904 & 4.628240 & 6895.238 \\
\hline Skewness & 0.734406 & 1.235431 & 0.901350 & 0.204048 & 1.360041 \\
\hline Kurtosis & 1.996529 & 3.296714 & 2.989323 & 3.668139 & 3.525324 \\
\hline Jarque-Bera & 5.010238 & 9.805896 & 5.145582 & 0.970508 & 12.15178 \\
\hline Probability & 0.081666 & 0.007425 & 0.076322 & 0.615541 & 0.002298 \\
\hline Sum & 1281558. & 211095.7 & 16196.59 & 667.9095 & 185437.1 \\
\hline Sum Sq. Dev. & $1.42 \mathrm{E}+10$ & $1.97 \mathrm{E}+09$ & 7224884. & 792.5623 & $1.76 \mathrm{E}+09$ \\
\hline Observations & 38 & 38 & 38 & 38 & 38 \\
\hline
\end{tabular}

Source: Author's Computation

A cursory look at Table 1 would reveal that the averages of RGP, INQ, CEX and TOP (that is, 33725.22, 5555.150, 426.2259, and 4879.924, respectively) are relatively high compared to LDR which averaged 17.57 for the period. These high averages for these variables signify instability owing to the high standard deviation values. The values of skewness are relatively low compared to those of the mean and standard deviation and this also shows that they all lie to the left, signifying that they are less than the value of the mean. The J-B statistic passed the significance test at the 10 per cent level for all the variables except for LDR, which stands at 0.970508 . The implication for these statistical results is that the density function of the series is non-normally distributed.

\subsection{Correlation Analysis}

The results of the correlation estimation strategy of the study are contained in Table 4.2, thus:

Table 2. Correlation Matrix

\begin{tabular}{|l|l|l|l|l|l|}
\hline & RGDP & INQ & CEX & LDR & TOP \\
\hline RGDP & 1 & 0.96127 & 0.910559 & 0.008789 & 0.957251 \\
\hline INQ & 0.96127 & 1 & 0.910136 & -0.06238 & 0.96199 \\
\hline CEX & 0.910559 & 0.910136 & 1 & -0.00656 & 0.860215 \\
\hline LDR & 0.008789 & -0.06238 & -0.00656 & 1 & -0.06386 \\
\hline TOP & 0.957251 & 0.96199 & 0.860215 & -0.06386 & 1 \\
\hline
\end{tabular}

Source: Author's Computation

From Table 2, it can be observed that INQ, CEX, LDR and TOP are all positively correlated to economic growth indicating that a strong relationship exists between RGDP (dependent variable) and the explanatory variables with the exception of LDR, which exhibited a value of 0.008789a positive nexus exist between the variables and INQ. Similar conclusion can also be held for CEX and TOP. However, with respect to LDR, all variables exhibited negative relationship with the exception of RGP.

\subsection{Unit Root Test Results}

The aim of unit root test is to ascertain the level of stationarity of the variables in the model. This test is necessary because time series data such as those utilized in the study are assumed to be non-stationary and, hence, it became important to perform a pre-test to ensure that there is a stationary co-integrating relationship among the variables of the study. The essence is to avoid the problem of spurious regression. Hence, all the variables of the study were subjected to stationarity tests using the Augmented Dickey-Fuller (ADF) approach. The results of the ADF tests thus obtained are reported in Table 3: 
Table 3. The Augmented Dickey Fuller (ADF) Unit Root Test Results

\begin{tabular}{|c|c|c|c|c|c|c|}
\hline \multirow{2}{*}{ Variables } & \multicolumn{3}{|c|}{ Level Form } & \multicolumn{3}{c|}{ First Difference } \\
\cline { 2 - 7 } & $\begin{array}{l}\text { ADF Test } \\
\text { Stat }\end{array}$ & $\begin{array}{l}\text { Critical } \\
\text { Value }\end{array}$ & Inference & $\begin{array}{l}\text { ADF Test } \\
\text { Stat }\end{array}$ & Critical Value & Inference \\
\hline LRGP & -1.50 & -3.54 & NS & -3.32 & -3.20 & S \\
\hline LINQ & -1.19 & -3.54 & NS & -4.53 & -3.54 & S \\
\hline LCEX & -1.34 & -3.54 & NS & -6.26 & -3.54 & S \\
\hline LDR & -5.07 & -3.56 & S & -6.20 & -3.54 & S \\
\hline DTOP & -2.60 & -3.54 & NS & -6.68 & -3.54 & S \\
\hline
\end{tabular}

Source: Author's Computation

Note: NS and S represent Non-stationary and stationary.

The results contained in Table 3 showed that all the variables of the study did not pass the test of stationarity in their level forms. However, they all passed the test of stationarity after first differencing at the 5 per cent and 10 per cent significant levels. Thus, it could be reasonably argued that the stationarity results obtained after first differencing are amenable to generalization to all time periods - past, present and future.

\subsection{Co-integration Test}

The co-integration test is usually conducted to establish whether or not a long term relationship exists among the variables in a model specification. Since all the variables became stationary in their first difference forms, a test of co-integration was carried out using the residuals obtained from regressing the dependent variable on the independent variables in the specification. The results thus obtained are contained in Table 4.4:

Table 4. Residual Based CointegrationTest Results

\begin{tabular}{lccc}
\hline \hline & t-Statistic & Prob. $^{*}$ \\
\hline \hline Augmented Dickey-Fuller test statistic & -11.53915 & 0.0000 \\
\hline Test critical values: & $1 \%$ level & -4.262735 & \\
& $5 \%$ level & -3.552973 & \\
& $10 \%$ level & -3.209642 & \\
& & & \\
\hline \hline
\end{tabular}

*MacKinnon (1996) one-sided p-values.

\section{Source: Authors Computation}

Table 4 above presents the co-integration test results. As can be inferred from the results, the hypothesis of stationarity of the estimated residuals cannot be rejected at the 1\%.5\%. and $10 \%$ level of significance, respectively. The implication of this empirical finding shows that there exists a long-run convergence/relationship between the dependent and explanatory variables of the study.

\subsection{OLS Estimates}

The results of the ordinary least squares estimates are reported in Table 4.5 below: 
Table 5. OLS Estimates for Long-run Results

Dependent variable: LRGP

\begin{tabular}{ccccc}
\hline \hline Variable & Coefficient & Std. Error & t-Statistic & Prob. \\
\hline \hline C & 8.602275 & 0.191300 & 44.96752 & 0.0000 \\
LCEX & -0.269414 & 0.044495 & -6.054956 & 0.0000 \\
LINQ & 0.258086 & 0.123133 & 2.095998 & 0.0438 \\
LDR & -0.007761 & 0.004198 & -1.848872 & 0.0735 \\
LTOP & 0.195646 & 0.106163 & 1.842887 & 0.0743 \\
\hline \hline & & & & 10.26894 \\
R-squared & 0.964556 & Mean dependent var & & \\
Adjusted R-squared & 0.960260 & S.D. dependent var & & \\
F-statistic & 224.5113 & & & \\
Prob(F-statistic) & 0.000000 & & & \\
\hline \hline
\end{tabular}

Source: Author's Computation

The result from Table 4.5 showed that the impact of industrial output on economic growth is positive and statistically significant the 5 per cent level. What this empirical finding signifies is that a one per cent rise in industrial output results led to a 0.25 per cent rise in economic growth in Nigeria during the period 1981 to 2018. Contrariwise, capital expenditure was negative but statistical significant at the 1 per cent level. The import of this finding is that a one per cent rise in capital expenditure resulted in a 0.26 per cent decrease in economic growth. The lending rate variable exhibited a negative impact on economic growth in Nigeria though it was statistically significant at the 10 per cent. The result suggests that a 1 per cent rise in lending rate instigated a 0.0077 per cent decrease in economic growth. Lastly, the trade openness variable exhibited a positive and statistical significant impact on economic growth in Nigeria at the 10 per cent level. Impliedly, a one per cent increase in trade openness resulted in a 0.19 per cent rise in economic growth in Nigeria. The summary statistics were robust and impressive. For example, the value of the coefficient of determination (R-squared) stood at approximately 96.5 per cent, while its adjusted R-squared counterpart stood at approximately at 96 per cent. These statistical results showed that the all the regressors put together were able to explain over 96 per cent of the systematic variations/changes in the regressand. These statistical results were supported by the value of the F-statistic (over 224.5) which clearly suggested that the model specified in the study possessed a large measure of overall significance.

\subsection{ECM Estimates}

Specifically worthy of note is the sign and statistical significance of the coefficient of the error correction term, $[\operatorname{ECM}(-1)]$. The negative sign of the coefficient estimate accords with the presumptive sign and suggested that temporary deviations from the equilibrium value of the data series of the industrial sector output are eliminated. Doing this certainly makes it possible to re-establish the long run equilibrium state. In other words, the error correction specification suggests the existence of the possibility of convergence of the prediction of the behavior of industrial sector output in Nigeria to its long term equilibrium value. Thus, it is appropriate to expect that any shock to the data series on the variables in the specification will recede over time. Accordingly, the results of the ECM estimates are reported in Table 4.6 below: 
Table 6. ECM Estimates

Dependent variable: LReal GDP

\begin{tabular}{|c|c|c|c|c|}
\hline Variable & Coefficient & Std. Error & t-Statistic & Prob. \\
\hline $\mathrm{C}$ & 8.361139 & 0.191500 & 43.66127 & 0.0000 \\
\hline LCEX & -0.199120 & 0.057437 & -3.466737 & 0.0018 \\
\hline LINQ & 0.399900 & 0.059416 & 6.730528 & 0.0000 \\
\hline LDR & -0.001268 & 0.005859 & -0.216409 & 0.8303 \\
\hline DTOP & 0.000101 & $5.06 \mathrm{E}-05$ & 1.988758 & 0.0570 \\
\hline $\operatorname{ECM}(-1)$ & -1.190005 & 0.350001 & -3.400004 & 0.0007 \\
\hline R-squared & 0.960224 & & Mean dependent var & 10.37249 \\
\hline Adjusted R-squared & 0.952858 & & S.D. dependent var & 0.528971 \\
\hline F-statistic & 130.3599 & & & \\
\hline Prob(F-statistic) & 0.000000 & & & \\
\hline
\end{tabular}

Source: Author's Computation

As Table 4.6 shows, the value of the constant term or intercept is positive and statistically significant at the traditional 1 per cent level. What this empirical result/finding denotes is that industrial sector output has positively and significantly impacted economic growth in Nigeria during the period 1981 to 2018. This empirical finding has suggested that a 1 per cent rise in industrial output resulted in approximately 836 per cent rise in economic growth in Nigeria. Similarly, the Table showed that trade openness positively and significantly impacted economic growth in Nigeria at approximately the 6 per cent level. In fact, a one per cent rise in trade openness resulted in a 0.0001 per cent increase in economic growth. The capital expenditure variable was found to have exerted a negative but significant impact on economic growth in Nigeria. As the result suggested that a 1 per cent rise in capital expenditure led to a 0.20 per cent decrease in economic growth. The lending rate variable was also found to have exhibited a negative but statistical significant impact on economic growth in Nigeria. What this empirical finding suggests is that a 1 per cent rise in lending rate resulted in a 0.0012 per cent decline in economic growth. The coefficient of determination (R-squared) stood at approximately 96 per cent, while its adjusted R-squared counterpart stood at over 95 per cent. The statistical outcomes showed that over 95 per cent of the systematic variations in economic growth were explained by all the independent variables put together; this is an attestation to a large measure of goodness-of-fit of the variables to the regression line. The value of the F-statistic, 103.3599 [.000], attested to the overall significance of the model estimated in the study.

The estimated value of the coefficient of the ECM, -1.190005, was negatively signed but statistically significant at the traditional 1 per cent level. This result implies that about 111.9 per cent disequilibrium in the system is offset by short-run adjustment to maintain long-run equilibrium periodically. The empirical findings have far-reaching implications for policies that are designed to affect the industrial sector output in Nigeria against the background that the variables that have been utilized in the specification of the model for this study. In other words these results conform to necessary condition for the existence of co-integrating relationship among the variables of the study.

\subsection{Granger Causality}

Pair-wise Granger Causality analysis was conducted in the study to establish the existence of causal relationship (unidirectional and bidirectional) between the variables employed in the study. The pair-wise Granger causality analysis results thus obtained in the study are reported in Table 4.7 below:

\begin{tabular}{|c|c|c|c|}
\hline Null Hypothesis: & Obs & F-Stat. & Prob. \\
\hline CEX does not Granger Cause RGP & 36 & 5.96272 & 0.0064 \\
\hline RGP does not Granger Cause CEX & & 4.38653 & 0.0210 \\
\hline INQ does not Granger Cause RGP & 36 & 0.95073 & 0.3974 \\
\hline RGP does not Granger Cause INQ & & 17.4483 & 8.E-06 \\
\hline LDR does not Granger Cause RGP & 36 & 0.23356 & 0.7931 \\
\hline RGP does not Granger Cause LDR & & 0.45368 & 0.6394 \\
\hline
\end{tabular}




\begin{tabular}{|c|c|c|c|}
\hline $\begin{array}{l}\text { TOP does not Granger Cause RGP } \\
\text { RGP does not Granger Cause TOP }\end{array}$ & 36 & $\begin{array}{l}1.99324 \\
12.2038\end{array}$ & $\begin{array}{l}0.1533 \\
0.0001\end{array}$ \\
\hline INQ does not Granger Cause CEX & 36 & 3.76028 & 0.0345 \\
\hline CEX does not Granger Cause INQ & & 1.84342 & 0.1752 \\
\hline LDR does not Granger Cause CEX & 36 & 0.29001 & 0.7503 \\
\hline CEX does not Granger Cause LDR & & 0.33963 & 0.7147 \\
\hline TOP does not Granger Cause CEX & 36 & 4.06707 & 0.0270 \\
\hline CEX does not Granger Cause TOP & & 4.26239 & 0.0232 \\
\hline LDR does not Granger Cause INQ & 36 & 0.22492 & 0.7999 \\
\hline INQ does not Granger Cause LDR & & 0.47885 & 0.6240 \\
\hline TOPdoes not Granger Cause INQ & 36 & 13.7683 & 5.E-05 \\
\hline INQ does not Granger Cause TOP & & 18.4876 & 5.E-06 \\
\hline TOP does not Granger Cause LDR & 36 & 0.29485 & 0.7467 \\
\hline LDR does not Granger Cause TOP & & 0.21817 & 0.8052 \\
\hline
\end{tabular}

Source: Author's Computation using E-view 10

The results in Table 7 showed that there existed a one-way causality between RGDP and INQ with causality running from RGDP to INQ, while a two-way causal relationship existed between CEX and RGDP. Unidirectional causality running from RGDP to TOP and INQ to CEX was also established. Lastly, a bi-directional causality was established between TOP and CEX; and between TOP and INQ.

\section{Stability Test}

A stability test helps to determine the nexus that exists between the dependent and the independent variables over time. To this end, a plot of cumulative sum of recursive residual (CUSUM) was conducted and the results thus generated are shown in Figure 4.1 below:

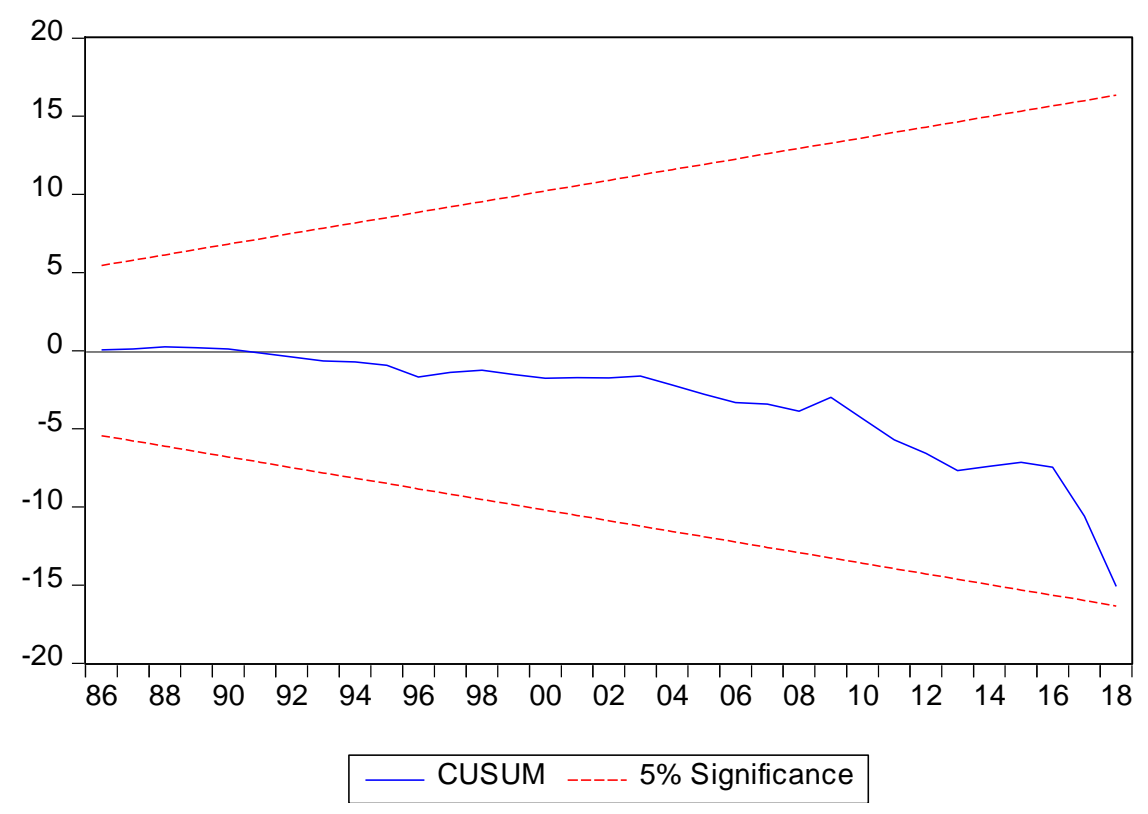

Figure 1. Stability Test

Source: Authors Computation 
It can be observed from the Figure 1 above that the plot lies between the critical bounds indicating that the model is structurally stable and can be relied upon for policy direction.

\section{Findings, Conclusions and Recommendations}

The study conducted an in-depth verification of the impact of industrial sector output on economic growth in emerging economies: evidence from Nigeria for the period 1981 to 2018.

\section{Summary of Findings}

Some of the major empirical findings of the paper showed that:

(1) Industrial output exerted a positive and significant impact on economic growth in Nigeria at the traditional 1 per cent level.

(2) The trade openness variable positively and significantly impacted economic growth in Nigeria at the 5 per cent level.

(3) The capital expenditure variable exhibited a positive but insignificant impact on economic growth in Nigeria during the same period.

(4) The lending rate variable appeared with a negative impact on economic growth in Nigeria for the period covered by the study.

(5) The summary statistics of the study were quite robust and impressive. For instance, the coefficient of determination (R-squared) and its adjusted counterpart (R-bar-squared) showed that all the independent variables put together were able to explain over 95 per cent of the systematic variations in the dependent variables; thus signifying that a large measure of goodness-of-fit to the regression line existed among the variables of the study.

\section{Conclusions}

The industrial sector of the Nigerian economy contributed minimally to the country's growth during the period 1981 to 2018. A lot of reasons could be ascribed to this abysmal contribution. For instance, there seemed to be the absence of an enabling environment that could have engendered the industrial performance in Nigeria to flourish.

\section{Recommendations}

Given the foregoing findings and conclusions, the following recommendations are put forward:

(1) That the industrial base of Nigeria as it is presently seems weak. Therefore, it needs to be strengthened with appropriate legal and regulatory frameworks that would attract both local and foreign investments to the sector to enable the sector contribute optimally to the country's gross domestic product (GDP) so as to be at par with its peer group members such as Argentina, Egypt, Hungary, India, among others.

(2) That the volume and value of trade openness with other countries of the world should be scaled-up, but with great caution, to elicit greater industrial sector output in Nigeria.

(3) That the authorities in Nigeria should more than ever before devote greater budgetary allocations to the industrial sector, especially the electricity power generation and distribution aspect, to lower the cost of production in the country. This would certainly reduce production costs which, in turn, would lead to greater industrial sector output.

(4) That the lending rate currently in operation in Nigeria, which is between 14 per cent and 20 per cent, seemed too high. It is thus not an overstatement to say that this scenario would discourage investors from borrowing to scale-up their productivity. There is no doubt whatsoever that this type situation is inimical to the growth of the industrial sector output and, invariably, economic growth. It is therefore strongly recommended that the monetary authorities in Nigeria should make frantic efforts to resolve this problem as quickly as possible to enhance the country's industrial sector output. This is considered imperative given the role the industrial sector plays in the total output of the economy serves enthrone sustainable growth and development.

\section{Declarations:}

\section{Competing Interests:}

There is no potential conflict of interest regarding the authorship and publication of this article.

Data and Material:

Available on request

Funding: 
All the financial requirements for the study were personally borne by the author.

\section{Author's Contributions:}

The study revealed that despite the various policy efforts made by the relevant authorities in Nigeria, the industrial sector still contributes poorly to economic growth. This is considered worrisome, bearing in mind that the capital expenditure for the sector is grossly inadequate. The ruling double-digits lending rate in the nation's credit market is excessively high. This is in spite of the fact that these two variables have a direct and proportional linkage with industrial sector development and, invariably, the sector's output.

\section{Acknowledgements:}

I sincerely acknowledge all the forerunners whose studies in the extant literature were reviewed and cited in the study.

\section{Author's Information:}

Not Applicable

\section{References}

Abdu, M., \& Anam, E. B. (2018). Evaluation of the Nigerian Industrial Sector and Economic Growth in the Face of Sustainable Development Goals. International Journal of Advanced Research in Public Policy, Social Development and Enterprise Studies, 3(1), 49-59.

Accounting Coach. (2020). Retrieved from https://www.accountingcoach.com

Adenomon, M. O., \& Oyejola, B. A. (2013). Impact of Agriculture and industrialization on GDP in Nigeria: Evidence from VAR and SVAR Models, MPRA Paper No. 75268, 1-32. Retrieved from https://mpra.ub.uni-muenchen.de/75268/

Akpan, E. S., Riman, H. B., Duke II, J., \& Mboto, H. W. (2012). Industrial production and non-oil export: Assessing the long-run implication on economic growth in Nigeria. International Journal of Economics and Finance, 4(2), 252-259.

Anyanwu, J. C., Oyefusi A., Oaikhenan, H., \& Dimowo, F. (1997). The Structure of the Nigerian Economy (1960-1997), Onitsha, Joanae Educational Publishers.

Barro, R. J. (1991). Economic growth in a cross section of countries. Quarterly Journal of Economics, 106, $407-473$. https://doi.org/10.2307/2937943

Barro, R. J., \& X. Sala-i-Martins (1997). Journal of Economic Growth, 2, 1-28. https://doi.org/10.1023/A:1009746629269

Bennett, K. O, Anyanwu, U. N., \& Kalu A. O. U. (2015). The effect of industrial development on economic growth (anempirical evidence in Nigeria 1973-2013),European Journal of Bus and Mgt, 7(13), 160-170.

Datahelp.imf.org (2020).

Gordon Scott. (2020): Investopedia (2020), https//www.investopedia.com

Gylych, J., \& Enwerem, H. I. (2016).Impact of industrialization on economic growth; experience of ten countries of ECOWAS.Conference paper on Social Science \& Law, Africa, At Abuja / Nigeria, 2.

Hendry, D. F. (1986). Econometric modeling with co-integrated variables: An overview. Oxford Bulletin of economics and statistics, 48(3), 201-212. https://doi.org/10.1111/j.1468-0084.1986.mp48003001.x

Huchet-Bourdon, M., Mouel, C. L., \& Vijil, M. (2018). The Relationship Between Trade Openness and Economic Growth: Some New Insights on the Openness Measurement Issue. The World Economy, 41(1), 1-356. https://doi.org/10.1111/twec.12586

Institute of International Finance. (2017). Capital Flows to Emerging Markets: A Brighter Outlook.

Intelligent Economist. (2020). https://www.intelligenteconomist.com

Izevbigie, J. N., Isikhuemen, A. H., \& Ogbeifun, I. M. (2020). Foreign aid inflows and economic growth in ECOWAS sub region. Journal of Academic Research in Economics, SpiruHaret University, Faculty of Law and Economics, Constanta 32-34 Unirii, Constanta, Romania, 12(1), 108-121.

Jelilov, G., Enwerem, H., \& Isik, A., (2016). The impact of industrialization on economic growth: the Nigeria experience (2000-2013). British Journal of Advance Academic Research, 5(1), 11-20.

Mandara, B., \& Ali, M. B. (2018). Appraisal of the impact of industrialization on economic growth in Nigeria, Journal of Bus and Mgt (IOSR-JBM) 20(1), 01-10.www.iosrjournals.org [Accessed April 2020]. 
National Bureau of Statistics. (2005).Statistical Bulletin and Annual Report.

National Bureau of Statistics. (2011).Statistical Bulletin and Annual Report.

National Bureau of Statistics. (2013).Statistical Bulletin and Annual Report.

Nationl Bureau of Statistics. (2018). Statistical Bulletin and Annual Report.

Nnanna, O. J., Englama, A., \& Odoko, F.O. (2004). Financial Markets in Nigeria. Central Bank of Nigeria Publication.

OECD. (2020). https://www.data.oecd.org

Okodua, H. (2012). Migrant workers' remittances and output growth in Sub Saharan African countries, European Scientific Journal, 8(19), 142-163.

Quaicoe, A., Aboagye, A. Q. Q., \& Bokpin, G. A. (2017). Assessing the impact of export processing zones on economic growth in Ghana. Research in International Business and Finance, 42, 1150-1163. https://doi.org/10.1016/j.ribaf.2017.07.052

Sen. (1983). The Economic Journal, 93 (December, 1983), 745-762. https://doi.org/10.2307/2232744

Senibi, K. V., Aiyepeku, A., Odutola, O., Ndaman, I., Eseoghene, O., Ogunlusi, T., \& Eldad, M., (2017). Industrial sector investment and industrial growth in Nigeria: A granger causality analysis, Int'l Journal of English Lit and Social Sciences (IJELS), 2(4), 1-9. https://doi.org/10.24001/ijels.2.4.1

Tamuno, S. O., \& Edoumiekumo, S. G. (2012). Industrialization and trade globalization: What hope for Nigeria? International Journal of Academic Research in Business and Social Sciences, 2(6), 157-170.

Todaro, M. P., \& Smith, S. C. (2011). Economic Development (11th ed.)

Trading Economics. (2020). Retrieved from https://tradingeconomics.com

Tutor 2U (2020). Retrieved from https://www.tutor2u.net

Udah, E. B. (2010). Industrial development, electricity crisis and economic performance in Nigeria. European Journal of Economics, Finance and Administrative Sciences, 18, 105-124.

Ughulu, S. E., \& Ajayi, M. O. (2020). Capital Market Operations and Economic Growth in Nigeria: An Empirical Investigation. International Journal of Advanced Engineering and Management Research, 5(3), 1-18.

Wikipedia (2020). Retrieved from https://www.len.m.wikipedia.org

World Bank, (2018). World Development Indicator, Washington D.C.

World Bank, (2019). World Development Indicator, Washington D.C.

World Economic Situation and Prospect, (2018). United Nations, New York.

\section{Copyrights}

Copyright for this article is retained by the author(s), with first publication rights granted to the journal.

This is an open-access article distributed under the terms and conditions of the Creative Commons Attribution license which permits unrestricted use, distribution, and reproduction in any medium, provided the original work is properly cited. 